\title{
Impact of Smartphone Usage on the Academic Performance among Medical Students
}

\author{
V. Santhi' ${ }^{1}$ B. Rajesh ${ }^{2}$ \\ 1Department of Anatomy, Sri Lakshmi Narayana Institute of Medical Sciences, Puducherry, Affiliated to \\ Bharath Institute of Higher Education and Research (BIHER) Chennai, Tamilnadu, India. ${ }^{2}$ Department of \\ Anatomy, Sri Lakshmi Narayana Institute of Medical Sciences, Puducherry, Affiliated to Bharath Institute \\ of Higher Education and Research (BIHER) Chennai, Tamilnadu, India.
}

\section{ABSTRACT}

\section{BACKGROUND}

Mobile phones are considered as an essential part of day to day life. But its excessive use is detrimental to the mind and body; especially, for the young population. Even though there are many reports regarding the issues related to excessive use of smartphones and its impact on the academic and social life of college going students, research related to medical students is sparse. The aim of this study is to determine the impact of smartphone usage on academic performance of a selected group of medical students using a structured questionnaire.

\section{METHODS}

A survey-based study has conducted among randomly selected MBBS students $(\mathrm{N}=200)$, comprising of 85 males and 115 females, in the age group of $17-25$ years. A self-administered and pre-tested questionnaire which includes questions on the effect of smart phone, was used.

\section{RESULTS}

Results of the survey showed that all the participants are using smart phones and agreed that it is an essential part of their life. Among these, only $12.2 \%$ of students are using it for academic purpose. Surprisingly $68.8 \%$ students use their mobile phone inside the classroom. $44.2 \%$ of the participants felt that their smartphones are distracting them from studies. They also reported that due to the overuse of smartphones they are unable to concentrate on studies (34.2\%), it affects study habits and leads to poor performance in exams (40\%), produces stress for the eyes $(21 \%)$ and a decrease in overall academic performance (29.1\%).

\section{CONCLUSIONS}

The present study group of medical students felt that overuse of smartphone is the main reason for their poor academic performance. They also realise the ill effect of overuse of mobile phones on health. The present study helped us to create awareness among the participants regarding the impact of overuse of smartphones and how it is influencing their academic activities. Universities and colleges can also create awareness regarding mobile phone use.

\section{KEY WORDS}

Smart Phone, Mobile Phone, Medical students, Poor Academic Performance

\author{
Corresponding Author: \\ Dr. B. Rajesh, \\ Professor, \\ Department of Anatomy, \\ Sri Lakshmi Narayana Institute of \\ Medical Sciences, Puducherry-605502, \\ Affiliated to Bharath Institute of Higher \\ Education and Research (BIHER) Chennai, \\ Tamilnadu, India. \\ E-mail: anat_rajesh@rediffmail.com
}

DOI: $10.14260 /$ jemds/2020/23

Financial or Other Competing Interests: None.

How to Cite This Article:

Santhi V, Rajesh B. Impact of smartphone usage on the academic performance among medical students. J. Evolution Med. Dent. Sci.2020;9(02):105-110,

10.14260/jemds/2020/23

Submission 18-06-2019,

Peer Review 27-12-2019,

Acceptance 02-01-2020,

Published 13-01-2020. 


\section{BACKGROUND}

Smartphone- a multi-purpose mobile computing devices, is an essential part of human life which has multimedia functionality along with voice calls and text messaging. As per a study in 2014, 1.85 billion people were using smart phone among the worldwide population. This number is expected to be 2.32 billion users in 2017 and in 2020 it is expected to reach 2.87 billion.(1) In India, the number of mobile phone users is 524.9 million as of 2013 and by 2019, it is predicted to reach 813.2 million.(2) Any new technologies, the young people are the first one to get exposed to it. The smart phones are changing the way they communicate with one another and also it plays a major role in their academic and social lives. The smart phones became the central to the identity of the adolescents and it is an important communication tool for young people among the peer group and being a part of the peer group. It has transformed their peer relationship into a truly networked society.(3) Nowadays, the mobile is a status symbol for many young people. The appearance of phone, features and personalised accessories attested to their phone's status and $60 \%$ of adolescents were keen to upgrade their mobile phone.(4) It is also seen as a fashion accessory by the young people that satisfies the need for individualisation by choosing their mobile phone wall paper, ring tones, phone covers, carry bags and other accessories needed for the phone.(5)

Majority of the researchers found that the mobile phones lead to problematic use in schools and colleges. In relation to the use of mobile phone there is a conflict in priority among young people, parents and teachers. Teachers concerned about discipline issues in the classroom, but for parents, they are concerned about being contact with their ward at any time.(5) According to Ling and Helmerson (2005), mobile phone "Is at cross purpose with the mission of school". In school, students are supposed to take their prescribed student role, free from contact with the world outside, with full concentration on their studies. Using mobile phones inside the school gives room to blend the student's role and finally it results in distraction and disruption from their academic work.(6) With the overuse of mobile phones and internet access, one can easily see the consequences in the academic performance and lifestyle of young people. There will be a continuous downward spiralling in the academic activity, increase in the cases of drop out, massive failures in exam and also malpractices in exam with the help of cell phone.(7)

Kubey et al states that heavy use of technology by the adolescents for recreational purposes is highly correlated with reduced academic performance. He also states that the internet use at late night, makes them to get less sleep and miss their classes.(8) In Japan, the results of a survey of youth trends showed that $68 \%$ of students received poor grades academically who owned a mobile phone.(9) Bianchi and Philips in 2005 introduced the concept of addiction to mobile phone use. Smart phone addiction became a globally emerging issue and it also affects the adolescents of India. (10) In November 2017, a survey conducted by AIIMS, Delhi and Maulana Azad Medical College at a health camp in Pragati Maiden. In this survey on 817 people [Including college and school students, young professionals], it was found that about $56 \%$ of the participants had at least one mobile phone behavioural addiction such as gaming, internet use and social media. (11) A new study has found out that anxiety and missing out an information makes the university students to check their mobile devices as many as 150 times in a day or an average. ${ }^{(12)}$ Jose de- sola et al reviewed about the problematic cell phone use with criteria similar to those established for substance addiction and pathological gambling. It has been associated with some personality variables such as extraversion, neuroticism, self-esteem, impulsive self-identity and self-image.(13) A study by Hafidha et aldefines smartphone addiction as a type of behaviour associated with a group of negative symptoms like disregard of harmful consequences, pre occupation, inability to control craving, productivity loss and feeling of anxiety.(14)

On 31st May 2011, the WHO confirmed that overuse of mobile phone indeed results in health risks and it classified cell phone radiation as a carcinogenic to humans.(15) Micro wave or Electromagnetic radiations from the mobile phone alter the electrical activity of brain and it results in numerous health effects such as headache, difficulty in concentration, loss of mental attention, increased reaction time, sleep disturbances, fatigue, stress, hearing and concentration problems and also these radiations damage the areas of brain associated with learning, memory and movements.(16) New pathological conditions like Nomophobia (No mobile phobia), FOMO (Fear of missing out), the fear of being without a cell phone, disconnect from the internet, Textaphrenia and Ringxiety- the false sensation of having received a text message or a call that leads to checking the device constantly and Textiety- the anxiety of responding immediately to a text message have been reported.(17)

Undoubtedly smart phones offer several conveniences in our life but also, we need to be aware of the negative consequences of its use particularly young adults who depends more on it. With this background, this study is focused on finding the impact of mobile phone use on academic performance of MBBS students.

\section{METHODS}

This study was conducted among medical students of Sri Lakshmi Narayana Institute of Medical sciences, Puducherry. A total sample of 200 undergraduate students were selected randomly, with 115 female participants and 85 male participants. These students came within the age range of $17-$ 25 years. For this study, we developed a structured questionnaire with items included demographic information like age and gender, self-reported mobile phone usage and effect of its use in academic activities. After obtaining the Institutional Review Board approval, this survey was conducted online. The students of selected batches were approached in the lecture hall and they were informed about the survey and their consent to participate in the study was obtained. The questionnaire link was sent to the students and the researcher explained the procedure to answer the questions. Then the students were asked to submit the filled forms. A self-administered process was used to collect the data, whereby the respondent himself reads the questions and give the answers with more information regarding the usage of their cell phone. Each participant was given an identification code to avoid double responding. 


\section{RESULTS}

The data was collected, and results were calculated by using simple statistical technique of drawing percentages and depicting graphs. As shown in Table 1, out of 200 respondents, 115 (57.5\%) were females and 85 (42.5\%) were males. The 127 respondents $(63.5 \%)$ were of age between $17-19$ years followed by 62 (31\%) students from the age group 20-22 years and only $11(5.5 \%)$ respondents belong to the age group 2325 years. It was noteworthy to mention that all the 200 respondents $(100 \%)$ were using smart phones.

\begin{tabular}{|c|c|c|}
\hline Characteristics & Total (N= 200) & Percentage \\
\hline $\begin{array}{c}\text { Gender } \\
\text { Male }\end{array}$ & 85 & 42.5 \\
\hline Female & 115 & 57.5 \\
\hline Age & 127 & 63.5 \\
\hline $17-19$ years & 62 & 31 \\
\hline $20-22$ years & 11 & 5.5 \\
\hline $23-25$ years & Table 1. Demographic Information \\
\hline \multicolumn{2}{|c}{} \\
\hline
\end{tabular}

A total of $32.5 \%$ (65) students are using mobile phone for about more than 3 years. $21.3 \%$ (42) respondents use their cell phone daily for about 5-10 hrs and $20.1 \%$ (40) students use it more at late night. 39.7\% (79) students keep their mobile phone on the bed while sleeping. Among these 200 respondents, $61.4 \%$ (121) of the students mostly use their phone to contact their parents and relatives and only $12.2 \%$ (24) are using it for academic purpose. 63\% (120) of students reported that they feel tempted to use their mobile phone if his/her friend is using nearby them, when they were studying. $30.2 \%(60)$ students accepted that they felt addict to their phone. $30.7 \%$ (61) students are having a feel of urge to answer a call or text immediately. The common health effect in this study was eye strain reported by $21 \%$ (42) students.

$57.4 \%$ (113) of students agreed that their mobile phone has more of the entertainment materials stored when compared to study materials (Figure 1). $70.5 \%$ (141) participants informed that they use mobile internet most commonly for entertainment purpose (Figure 2). 59\% (118) students, it's more than half of our participants accepted that their academic performance can be increased without mobile phone usage (Figure 3). We also found some of the positive perceptions of mobile phone use by students in our study such as $46.5 \%$ students says that mobile phone is assisting them in learning new things and $41 \%$ students accepted that their mobile phone has increased their searching and learning skills. Table 2. Shows the how the mobile phone is influencing them academically.

\begin{tabular}{|c|c|c|}
\hline Characteristics & Total (N= 200) & Percentage \\
\hline Using mobile inside classroom & 137 & 68.8 \\
\hline Distracting from studies & 88 & 44.2 \\
\hline Lack of concentration in studies & 68 & 34.2 \\
\hline Affecting study habits and results in exam & 80 & 40 \\
\hline $\begin{array}{c}\text { Academic performance is decreased } \\
\text { because of frequent use of mobile phone. }\end{array}$ & 58 & 29.1 \\
\hline \multicolumn{2}{|c|}{ Table 2. Information } \\
\hline
\end{tabular}

The following are the figures depicting the percentage of student's response to some questions-
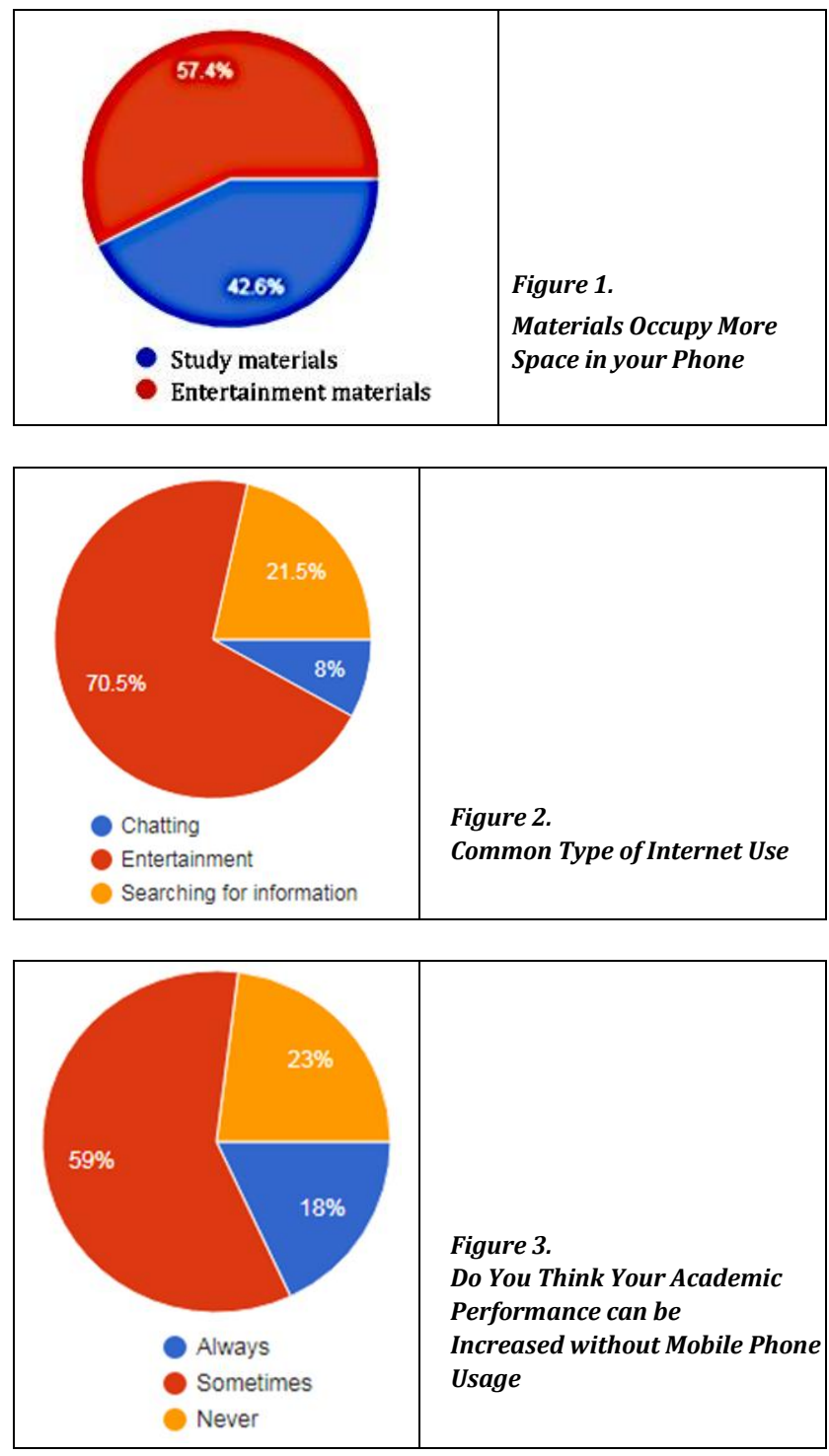

\section{DISCUSSION}

This study aimed to reveal the impact of smart phone usage on the academic performance among the medical college students. Cell phones play an important role in our life. Along with keys and money, the mobile phone also became one of the survival tool most people carry with them.(18) Using a mobile phone makes the communication possible anywhere at any time and it becomes a vehicle for self-expression and selfidentity. The young people are now so used for doing multitasking works and also the mobile phones are influencing the communication between the young generation people, it affects the conversational skills and self-disclosure. A new way of language with short hand is becoming popular among the students.(19)

"Smart phone dependency, Hedonism and Purchase behaviour: Implications for digital India initiatives" a study conducted by Aligarh Muslim University and funded by Indian council for social science research, found that only $26 \%$ respondents indicate the primary use of smartphone for calling purpose, remaining respondents use it for other purposes. The study also finds out that $23 \%$ of people log in more than 8 hours/day.(12) 
On September 16, 2008, the Orissa government announced that it has banned the mobile phones usage inside college campuses. The higher education minister Samir Dey said that "The mobile phones are found to be a disturbing element in college campus. Therefore, we have banned it in the campus," he also adds that the order would be implemented in both government and nongovernment colleges across the state.(20) Many researchers across the worldwide studied how the smart phones are influencing the academic as well social activities of the students. The cultural background can also impact the way the technology is perceived. Smart phones disrupt teaching and reducing the attention of students in class which results in negative educational outcomes as reported by school and educational settings.(21) Most of the students are blaming their undiscriminating use of mobile phone is responsible for their poor academic performance. They use mobile phone to access social network websites more than to learn e-books. ${ }^{(22)}$ Frequent calls and messages from the friends and other people are not allowing students to complete their academic work on time.(15) The teenagers who stayed up late night and use their phone during sleep hours are more prone for day time sleepiness in the class rooms. This eventually results in their decreased academic performance.(23) The findings of Meta-analysis approach by Sanjeev reveals that smart phone usage has significant effect in causing psychological problems, affects the classroom performance of students, hindering the studies, eating habits, results in stress etc. (24)

The findings of the study by Haruna et al revealed that using of mobile phone significantly influence the academic performance of both gender of secondary school students of Nigeria and also the study finds out that age difference and gender was not a significant factor in mobile phone usage, it affects equally all the students.(7) In a study by Mahboub among the middle eastern youth, he points out that $67 \%-70 \%$ of students claimed that new information technology is distracting them from studies.(25) An exploratory study of college students in Taiwan by Yi Fen Chen, indicates that the frequent usage of smart phone affects the academic learning and he also noted that Taiwanese female students were heavy mobile users when compared to their male peers.(26) In an attempt to study the effect of smart phone usage on the university students of UK by Fowler, he noted that participants experience a sense of compulsion with the use of mobile phone, they are constantly checking their emails and texts. He also mentioned one comment by a participant that "Nothing happened in the last 5 minutes but I still check it". This clearly shows that how mobile phones are distracting the students. (27)

A survey on smart phone usage among Korean people depicted that $83.6 \%$ of Koreans aged over 3 years were found to use a cell phone and the prevalence of addiction to mobile phone in Korean middle school students was $30.9 \%$. This is very high rate when compared with the rate in other countries.(28) India stands on second place with more cell phone subscribers next to China which stands at first place. Inside the college campuses of U.S, students fill the time between classes by using their mobile phone and usage of cell phone is spilling in library, classroom and even in bathroom.(18) Akansha et al researched on the effects of excess usage of mobile phone on the mental health and quality of life of adolescents. And it was found that the limited users of smart phones have better mental health and quality of life than the unlimited users.(29) Subbha et al in their study report that $34.6 \%$ of students have the symptoms of ringxiety and $49.6 \%$ who had ringxiety reported that their studies were hampered as a result of talking too much on phone. A majority of students (51\%) were found to communicate with their parents.(30) This was similar to our study where $61.4 \%$ students used their phone to communicate parents.

The young generation people who spend more time on their cell phone are more susceptible to psychological disturbances. Psychiatrist considered mobile phone addiction to be an obsessive compulsive disorder(OCD).(31) Excessive mobile phone use was observed among medicine post graduates which results in unstable mental health status and depression.(32) Attilla et al reported a case of 18 year old girl who has severe smart phone addiction and she fits to the criteria of behavioural addictions as well as for criteria of addiction to gambling disorders.(33) Agrawal et al (2008) reported that male fertility may be more vulnerable to damage as a result of cell phone radiation as they were able to degrade the quality of sperm, lower sperm motility, sperm viability and also some mutations in its DNA which changes the morphology of sperm. ${ }^{(34)}$ Seong Yeol investigated that using mobile phone with forward head posture results in muscle fatigue and pain in the neck and shoulder region.(35)

Some students are aware of their addiction to smart phone. They realise sometimes that their phone usage time is longer than they planned and try to shorten the time, but they fail to do so because of their addiction. In addition to poor academic performance, the smart phone usage disturbs the daily life activities and relationships with their family members also hampered. (36) Few studies proved that this mobile technology has sometimes increased the academic activities of students. They are using it as a positive tool for recording notes in the class room, to capture the scripts, hand written notes from books etc., It saves time and increase productivity, increased searching and learning skills and to create positive feeling among their peer group.(37) In a study by Tirupura Sundari, $39.3 \%$ agreed that their academic performance is increased due to mobile technology and $37.4 \%$ said it also assists them in learning. (38)

$90 \%$ or more of students agreed that smart phone is really helps them to achieve their educational objectives and also more or less same number of students complained the disturbance in the studies because of the smart phone.(39) According to students, the positive effects of mobile phone use is more on their study habits and social relationships than the negative effects, but for the teachers and parents the mobile phone use has more negative impact on students.(40) Almost half of the internet users are between 18 and 25 years of age. To these youth while this advanced technology is building bridges between them and distant from others, at the same time it is also building even stronger walls between them and their families and friends. (25) Rodney suggests that the college administrators and faculties can utilize different teaching methods that do not involve the modern technology so that, the students are forced to spend less time from the technology. ${ }^{(41)}$

Some of the measures to be taken by students as they told by themselves in our study are reported in the following-

- $\quad$ "I should take a decision to reduce the usage of mobile phones" 
- "Cut off net connection"

- "Control myself"

- $\quad$ "Restrict mobile usage fixed time for using mobile per day"

- $\quad$ "Using phone at one particular time every day and use it for emergencies only"

- "Should conduct some awareness programmes"

- "Regular (Once in a week) seminar and obtaining statistics on mobile usage"

- "Using basic model phones"

- "I should stop or switch off my phone while studying"

- "Control ourselves from using the mobile phone. It should be used in such a way that we should not be addicted by it"

\section{CONCLUSIONS}

The present study group consisted of medical students. They felt that overuse of smartphone is the main reason for their poor academic performance. They also realise the ill effect of overuse of mobile phones on health. The present study helped us to create awareness among the participants regarding the impact of overuse of smartphones and how it is influencing their academic activities. Universities and colleges can also create awareness regarding mobile phone use.

\section{REFERENCES}

[1] Number of smartphone users worldwide from 2014 to 2020. [cited $2019 \quad$ Feb 14$]$. https://www.statista.com/statistics/330695/numberof-smartphone-users-worldwide/

[2] Share of mobile phone users that use a smartphone in India from 2014 to 2019 [cited 2019 Feb 14]. https://www.statista.com/statistics/257048/smartpho ne-user-penetration-in-india/

[3] Williams S, Williams L. Space invaders: the negotiation of teenage boundaries through the mobile phone. Social Rev 2005;53(2):314-31.

[4] Netsafe. The text generation. Mobile phones and New Zealand youth: a report of result from the internet Safety Group's survey of teenage mobile phone use. 2005.

[5] Srivastava L. Mobile phones and the evolution of social behaviour. Behav Inf Technol 2005;24(2):111-29.

[6] Ling R, Helmersen P. It must be necessary, it has to cover a need: the adoption of mobile telephony among preadolescents and adolescents. Conference on the Social Consequences of Mobile Telephony 2000;16.

[7] Rabiu H, Muhammed AI, Umaru Y, et al. Impact of mobile phone usage on academic performance among secondary school students in Taraba State, Nigeria. Eur Sci Journal ESJ 2016;12(1):466.

[8] Kubey RW, Lavin MJ, Barrows JR. Internet use and collegiate academic performance decrements: early findings. J Commun 2001;51(2):366-82.

[9] Auckerman W. Survey shows cell phone secrets of Japanese youth. 2001. Internetnews.com. http://news.earthweb.com/bus-

news/article.php/548021.

[10] Bianchi A, Phillips JG. Psychological predictors of problem mobile phone use. Cyberpsychol Behav 2005;8(1):39-51.

[11] Sharma P. Mobiles \& internet are trapping the youth, says survey by top hospitals. 2018 [cited 2019 Feb 28]. https://www.indiatoday.in/mail-today/story/mobilesinternet-are-trapping-the-youth-says-survey-by-tophospitals-1180599-2018-03-02

[12] Agha E. 150 times a day: study shows indian students' alarming smartphone addiction. 2018 [cited 2019 Feb 28]. https://www.news18.com/news/india/accordingto-new-study-students-check-their-mobile-devices-asmany-as-150-times-in-a-day-1720539.html

[13] Gutiérrez JDS, de Fonseca FR, Rubio G. Cell-phone addiction: a review. Front Psychiatry 2016;7:175.

[14] Al-Barashdi HS, Bouazza A, Al Zubaidi A. Psychometric Properties of Smartphone Addiction Questionnaire (SPAQ) among Sultan Qaboos University Undergraduate Students. J Educ Psychol Stud (JEPS) 2014;8(4):637.

[15] Acharya JP, Acharya I, Waghrey D, et al. A study on some of the common health effects of cell-phones amongst college students. J Community Med Health Educ 2013;3:214.

[16] Sarfaraz S, Bano T, Fatima W, et al. Mobile phones: a threat to health of young generation? Eur J Pharm Med Res 2015;2(7):17-22. www.ejpmr.com

[17] Taneja C. The psychology of excessive cellular phone use. Delhi Psychiatry J 2014;17(2):448-51.

[18] Emanuel RC. The American college student cell phone survey. Coll Stud J 2013;47(1):75-81. http://ovidsp.ovid.com/ovidweb.cgi?T=JS\&PAGE=refere nce $\& D=$ psyc10\&NEWS $=N \& A N=2013-10664-008$.

[19] Cooper C. The influence of the mobile phone on young adult communication. Prof Commun Transl Stud 2017;10:12-21.

[20] Goswami V, Singh DR. Impact of mobile phone addiction on adolescent's life: a literature review. Int J Home Sci 2016;2(1):69-74. www.homesciencejournal.com

[21] Campbell M. The impact of the mobile phone on young people's social life. In: Bailey C, Barnett K, eds. Social change in the 21st Century 2005 Conference Proceedings: Queensland University of Technology, Australia, 2005: p. 1-14.

[22] Jumoke S, Blessing O. Analysis of mobile phone impact on student academic performance in tertiary institution. Int J Emerg Technol Adv Eng 2015;5(1):2250-459.

[23] Nathan N, Zeitzer J. A survey study of the association between mobile phone use and daytime sleepiness in California high school students. BMC Public Health 2013;13:840.

[24] Davey S, Davey A. Assessment of smartphone addiction in Indian adolescents: a mixed method study by systematicreview and meta-analysis approach. Int J Prev Med 2014;5(12):1500-11.

[25] Hashem ME. Impact and implications of new information technology on Middle Eastern youth. Global Media J: American Edition 2009;8(14):1-25.

[26] Chen YF. Social phenomena of mobile phone use: an exploratory study in Taiwanese college students. J Cyber Culture Inf Soc 2006;11(11):219-44. 
https://www.researchgate.net/publication/237404397_ Social_Phenomena_of_Mobile_Phone_Use_An_Explorator y_Study_in_Taiwanese_College_Students 12

[27] Fowler J, Noyes J. From dialing to tapping: university students report on mobile phone use. Procedia Manuf 2015;3:4716-23.

http://dx.doi.org/10.1016/j.promfg.2015.07.568

[28] Cha SS, Seo BK. Smartphone use and smartphone addiction in middle school students in Korea: Prevalence, social networking service and game use. Heal Psychol Open 2018;5(1):2055102918755046.

[29] Srivastava A, Ram KT. Effect of excess use of cell phone on adolescent's mental health and quality of life. 2013;2(I):110.

[30] Subba SH, Mandelia C, Pathak V, et al. Ringxiety and the mobile phone usage pattern among the students of a medical college in South India. J Clin Diagnostic Res 2013;7(2):205-9.

[31] Nishad P, Rana AS. Impact of mobile phone addiction among college going students. Adv Res J Soc Sci 2016;7(1)111-5.

[32] Tavakolizadeh J, Atarodi AR, Ahmadpour S, et al. The prevalence of excessive mobile phone use and its relation with mental health status and demographic factors among the students of Gonabad University of Medical Sciences in 2011 - 2012. Razavi Int J Med 2014;2(1):1-7.

[33] Körmendi A, Brutóczki Z, Végh BP, et al. Smartphone use can be addictive? A case report. J Behav Addict 2016;5(3):548-52.
[34] Aggarwal M, Grover S, Basu D. Mobile phone use by resident doctors: tendency to addiction-like behaviour. Ger J Psychiatry 2012;15(2):50-5.

[35] Kim SY, Koo SJ. Effect of duration of smartphone use on muscle fatigue and pain caused by forward head posture in adults. J Phys Ther Sci 2016;28(6):1669-72.

[36] Md. Arefin S, Md. Islam R, Ameen M, et al. Impact of smartphone addiction on academic performance of business students: a case study. Indep J Manag Prod 2017;8(3):629.

[37] Johnson S, Natarajan R. Academic use of smart phones among the students of business schools in uae -a study. KIIT J Libr Inf Manag 2017;4:32-6.

[38] Sundari TT. Effects of mobile phone use on academic performance of college going young adults in India. Int J Appl Res 2015;1(19):898-905. www.allresearchjournal.com

[39] Soomro LA, Tunio S. Impact of usage of cellular phones on study habbits of students and their psycho social development: a case study of Sindh University students. Natl Conf Role Non-governmental Organ Priv Sect Soc Econ Dev Pakistan, Mirpur Khas 2009.

[40] Rasheed A, Amin S, Umair A. Effect of using habits of cell phone on the study of the students: a case study on parents and teachers of Sargodha city. Asian J Empir Res 2014;4(4):254-62.

[41] Bragdon RA, Dowler K. College student technology use and academic performance. Int $\mathrm{J}$ Humanit Soc Sci 2016;6(1):12-22. 